\title{
ПРОЯВ СЕРЕД ПОТОМСТВА ПЕРШОГО БУЛЬБОВОГО ПОКОЛІННЯ ГІБРИДІВ ВІД ВНУТРІШНЬОВИДОВИХ ТА МІЖВИДОВИХ СХРЕЩУВАНЬ СЕРЕДНЬОЇ МАСИ БУЛЬБ
}

\author{
Подгаєцький Анатолій Адамович \\ доктор сільськогосподарських наук, професор \\ Сумський національний аграрний університет, м. Суми, Україна \\ ORCID: 0000-0002-2130-8835 \\ podgaje@ukr.net
}

Кравченко Наталія Володимирівна

доктор сільськогосподарських наук, доцент

Сумський національний аграрний університет, м. Суми, Україна

ORCID: 0000-0002-4190-0924

kravchenko_5@ukr.net

Крючко Людмила Василівна

кандидат сільськогосподарських наук, доцент

Сумський національний аграрний університет, м. Суми, Україна

ORCID: 0000-0003-0528-210X

ludmila-kruchko@meta.ua

Гнітецький Максим Олегович

аспірант

Сумський національний аграрний університет, м. Суми, Україна

ORCID ID 0000-002-8088-2677

Наведені результати дослідження свідчать про вище варіювання середньої маси бульб у сортів-компонентів схрещування (18-84 г), порівняно з міжвидовими гібридами, їх беккросами (27-46 2). Навпаки, найбільше значення нижньої межі лімітів популяцій від внутрішньовидового схрещування було 15 г, а від беккросування у п'яти комбінацій (25 \% від усіх) - 20 г. Подібне стосувалось верхньої межі лімітів, відповідно, 130 і 205 г.

Доведено, що різниця між середнім популяційним проявом показника значно більша серед комбінацій від беккросування (25 г з межами 23-48 г), ніж від внутрішньовидових схрешувань, відповідно, 11 і $30-41$ г. Виявлений значний вплив компонентів схрещування на прояв ознаки серед потомства.

Встановлено найбільший вплив запилювачів на прояв середньої маси бульб поміж потомства за участю сорту Подолія. Різниця між комбінаціями становила 8 г. Лише невеликою мірою поступались їй блоки популяцій з сортами Тирас (материнська форма) і Подолянка (запилювач - 7 2), Протилежне стосувалось двох комбінацій з материнською формою беккросом $10.6 Г 38$ з різницею 2 г. Встановлений реципрокний ефект середнього прояву ознаки в потомства за участю сортів Базис і Подолія (різниця 5 г) та Струмок і Подолія з різницею 11 г.

Тільки у однієї комбінації від внутрішньовидових схрещувань та в чотирьох від беккросування виділені гібриди з середньою масою бульб 100 г і більше. Лише в семи популяціях (29 \% від загальної кількості) величина істинного гетерозису мала додатне значення, хоча це не відносилось до жодної з внутрішньовидовим походженням. У 20-и комбінаціях ступінь трансгресії мав додатну величину і лише в трьох не виявлено частоти трансгресії.

Ключові слова: картопля, внутрішньовидові та міжвидові схрещування, середня маса бульб, батьківські форми, реципрокний ефект, гетерозис, трансгресії, ступінь френотипового домінування.

DOI https://doi.org/10.32845/agrobio.2021.2.7

Вступ. Картопля - одна з найпопулярніших і найбільш поширених сільськогосподарських культур у світі (Meenakshi, 2017), а для багатьох країн вона є стратегічним продуктом (Saynakova et al., 2018). На сучасному етапі розвитку картоплярства дуже велика увага приділяється характеристиці сортів. Кожен з них повинен мати хоча б середній прояв близько 50-и господарсько-цінних ознак (Ross, 1986). Середня маса бульб - одна з найголовніших (Gopal, 1992), бо її проявом регламентується не лише продуктивність (урожайність), але й напрям використання продукції.

Вирішити численні проблеми картоплярства вдалося завдяки поширенню міжвидової гібридизації, що дозволило значно розширити генофонд картоплі, в тому числі створити різноманіття вихідного селекційного матеріалу (Podhaietskyi, 2012; Kiru, Rogozina, 2017). Останнім часом створені сорти за участю шести і більше видів, що сприяло підвищенню споживчої якості сортів (Antonova et al., 2016; Meenakshi Kumari et. al., 2017). Водночас, у родоводі сортів, створених за участю дикорослих та культурних співродичів, інтрогресовані гени невеликої частини складових генофонду (не більше 15-17 видів) (Bradshaw, 2009; Slater et al., 2014; Castaneda-Alvarez et. Al., 2015).

Вимоги до величини бульб у зразків значно різняться залежно від напряму їх використання. Наприклад, для столового використання вони не повинні бути дуже великими, або дрібними (Ross, 1986). Інші вимоги до бульб, 
які переробляються на картоплю фррі. Їх індекс повинен бути не менше 1,7, глибина вічок до 1,3 мм, уміст сухих речовин не менше $20 \%$, а редукуючих цукрів не більше 0,5 \%. Бульби також повинні мати привабливе забарвлення м'якуша (Banadysev et al., 2003).

Створення сортів інтенсивного типу великою мірою передбачає наявність бульб, як мінімум, середнього розміру (Osypchuk, 2002). Численні створені сорти характеризуються оптимальною масою бульб. Серед доробку українських селекціонерів це такі сорти: Доброчин, Водограй, Пост 86 (Bondus et al., 2009), Надійна, Віринея (Podhaietskiy et. al., 2014), білоруської селекції: Бриз, Маг, Ветразь, Здабиток, Акцент та Універсал (Kovalenko, 2013), а також інших країн: Sola, Pamir, Porta, Svatava, Berolina, Korreta (Bondus et al., 2009). Велике значення має маса бульб з точки зору технології вирощування та зберігання картоплі (Engel, 1957; Podhaietskiy, 2002).

На думку численних дослідників середня маса бульб контролюється полігенами, причому більш тісний зв'язок мав місце між згаданою ознакою та врожайністю, ніж урожайністю та кількістю бульб у гнізді, що дозволило стверджувати про більшу стабільність прояву цієї складової урожайності, порівняно з кількістю бульб (Engel, 1957).

Виділені сорти, які добре передають великобульбовість потомству. Серед них особливо виділились сорти Олімпія, Швальбе Сабіна (Moller, 1965). Для європейських сортів оптимальною вважається наявність у гнізді 12-14 бульб вирівняного розміру (Schick \& Hopfe, 1962). Як і будь-якій полігенній ознаці середній масі бульб властивий гетерозис прояву серед потомства. Умова для його реалізації - гетероалелізм в контролі ознаки (Rowe, 1967; Mendoza \& Hyines, 1973; Skiebe, 1977).

Мета дослідження - визначити прояв серед гібридів першого бульбового покоління, одержаних від внутрішньовидових та міжвидових схрещувань середньої маси бульб, прояв ознаки у компонентів схрещування, виявити залежність між вираженням ознак.

Матеріали і методи досліджень. Дослідження проводились у Сумському національному аграрному університеті на дослідному полі кафедри біотехнології та фітофрармакології.

Компонентами схрещування використтані міжвидові гібриди, одержані за участю диких S. bulbocastanum Dun., S. demissum Lindl., S. acaule Bitt., та культурних: S. phureja Juz. et Buk., S. andigenum Juz. et Buk., S. tuberosum L. видів, а також сортів, у походженні яких ці види були присутні: Базис, Подолянка, а також сортів від внутрішньовидових схрещувань: Тирас, Лєтана, Партнер, Явір, Подолія. Сортами-стандартами використані Тирас, Явір і Случ.

Оцінку прояву ознаки проводили на матеріалу першого бульбового покоління гібридів згідно методики селекційно-генетичних досліджень 3 картоплею (Metodychni ..., 2002). Статистичну обробку даних проводили згідно П. Ф. Рокицького (Rokitskiy, 1973) з використанням пакета «Microsoft Excel». Агротехніка та догляд за рослинами картоплі загальноприйняті для Сумської області.

Результати. За середньою масою бульби компонентів схрещування дуже різнились. Це стосувалось як сортів внутрішньовидового походження, так і міжвидових гібридів, їх беккросів (табл. 1). Поміж перших особливо вдало реалі- зував свій потенціал сорт Партнер з проявом ознаки 84 г. Невеликою мірою поступався йому у цьому відношенні сорт Явір - 78 г. Протилежне викладеному стосувалось сорту Зелений - 18 г, Верді - 26 г, Подолія - 31 г. У цілому, більшість сортів, які залучали в схрещування, в умовах періоду вегетації картоплі і 2018 року характеризувались відносно низькою середньою масою бульб.

Таблиця 1

Середня маса бульб батьківських форм та їх середнє значення, 2018 р.

\begin{tabular}{|c|c|c|c|c|}
\hline \multirow{2}{*}{$\begin{array}{c}\text { № } \\
\text { комбінації }\end{array}$} & \multirow{2}{*}{ Походження } & \multicolumn{3}{|c|}{ Маса бульб, г } \\
\hline & & 우 & 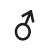 & середнє \\
\hline 1 & $\begin{array}{c}\text { Тетерів x Околиця } \\
\text { (90.817c4 x } \\
\text { Белла роза) }\end{array}$ & 63 & 26 & 44 \\
\hline 4 & $\begin{array}{c}\text { Верді x Базис } \\
\text { (85.291с12 x } \\
\text { Багряна) }\end{array}$ & 26 & 38 & 32 \\
\hline 5 & Верді x 81.459c18 & 26 & 27 & 26 \\
\hline 6 & $\begin{array}{c}\text { Зелений гай x } \\
\text { Подолянка (Аусонія } \\
\text { x 88.1439с6) }\end{array}$ & 18 & 36 & 27 \\
\hline 7 & Верді x Подолянка & 26 & 35 & 31 \\
\hline 8 & Тетерів x Подолянка & 63 & 35 & 49 \\
\hline 9 & $\begin{array}{l}08.195 / 73 \mathrm{x} \\
\text { Подолянка } \\
\end{array}$ & 35 & 35 & 35 \\
\hline 10 & 08.195/73 x Партнер & 35 & 84 & 59 \\
\hline 11 & 08.195/73 x Лєтана & 35 & 54 & 45 \\
\hline 12 & 08.195/73 x Мілавіца & 35 & 32 & 34 \\
\hline 13 & 08.195/73 x Тирас & 35 & 55 & 45 \\
\hline 14 & $10.6 Г 38$ x Подолія & 46 & 31 & 39 \\
\hline 15 & $\begin{array}{c}10.6 Г 38 \mathrm{x} \\
\text { Білоруська } 3 \\
\end{array}$ & 46 & 26 & 36 \\
\hline 16 & Подолія x Базис & 31 & 38 & 34 \\
\hline 18 & Подолія х Струмок & 31 & 46 & 39 \\
\hline 19 & $\begin{array}{c}\text { Поліське джерело x } \\
\text { Базис } \\
\end{array}$ & 32 & 38 & 35 \\
\hline 20 & Тетерів x Базис & 63 & 38 & 50 \\
\hline 21 & Тетерів x Струмок & 63 & 46 & 55 \\
\hline 22 & Базис x Тирас & 38 & 55 & 47 \\
\hline 23 & Базис x Подолія & 38 & 31 & 34 \\
\hline 24 & Струмок x Подолія & 46 & 31 & 39 \\
\hline 25 & Струмок х Явір & 46 & 78 & 62 \\
\hline 26 & Подолія x 81.459c18 & 31 & 27 & 29 \\
\hline 28 & Багряна x 89.202c79 & 42 & 32 & 37 \\
\hline
\end{tabular}

Ще більшою мірою викладене стосувалось міжвидових гібридів, їх беккросів. Максимальне вираження показника відмічене в беккроса 10.6ГЗ8 - 46 г. Значно меншим воно спостерігалось у сорту міжвидового походження Базис -38 г. Дуже низький прояв ознаки мали: міжвидовий гібрид 81.459c18 - 27 г та сорт міжвидового походження Околиця - 26 г.

Серед сортів-стандартів також мала місце відмінність за середньою масою бульб. Максимальним про- 
явом ознаки характеризувався середньостиглий сорт Явір - 78 г, що в 1,4 рази більше порівняно з сортом Тирас і у 2,1 рази за співставлення з сортом Случ.

Середнє батьків відображало співвідношення величин показника компонентів схрещування. Тільки в чотирьох пар: 08.195/73 і Партнер, Тетерів і Базис, Тетерів і Струмок та Струмок і Явір середнє батьків сягало 50 г і більше. Можна припустити, що більшою мірою, ніж спадковість, негативно вплинули на середню масу бульб умови вирощування. Адже, для висаджування використовували, навіть, малі бульби, які не могли у несприятливих метеорологічних умовах сформувати нові, хоча $б$ середні за величиною. Мінімальне значення нижньої межі лімітів знаходилось в межах 7-20 г (табл. 2). Перша величина стосувалось комбінації Верді х Базис, а остання виявлена в п'яти популяціях.

Значно більшою мінливістю характеризувалась максимальна величина лімітів. Найменше значення показника мало місце в популяції Тетерів х Околиця - 40 г. Лише на 1 г більше це виявлено в комбінації Подолія х 81.459c18. Близькі дані до викладених відмічені серед потомства з походженням Поліське джерело х Базис - 45 г.
Водночас, у окремих популяціях верхня межа лімітів знаходилась на дуже високому рівні. Наприклад, серед гібридів 08.195/73 х Тирас вищипився з середньою масою бульб 250 г. Значно нижчий прояв ознаки, ніж у згаданої комбінації, спостерігався серед гібридів з походженням Верді х 81.459c18 - 183 г. Отже, залежно від материнської форми за участю міжвидового гібрида 81.459c18 можна отримати як дрібнобульбове, так і великобульбове потомство. У цілому, у п'яти комбінаціях максимальне значення лімітів сягало 100 г і більше.

Як свідчать отримані дані, різниця лімітів головним чином залежала від найбільшої їх величини. Лише в трьох популяціях: Верді х 81.459с18, 08.195/73 x Тирас і Струмок х Подолія величина згаданого показника перевищила 100 г. Проте, у двох серед загальної кількості: Тетерів х Околиця і Подолія х 81.459c18 вона була дуже низькою, відповідно, 23 і 28 г.

Важливим показником характеристики потомства вважається середнє популяційне вираження ознаки. Як кращі виділені з походженням Зелений гай х Подолянка 48 г і 08.195/73 х Подолянка та 08.195/73 х Тирас - по 47 г. Протилежне викладеному стосувалось чотирьох

Таблиця 2

Середня маса бульб потомства від міжвидових та міжсортових схрещувань, 2018 р.

\begin{tabular}{|c|c|c|c|c|c|c|c|c|}
\hline \multirow{2}{*}{$\begin{array}{c}\text { № } \\
\text { популяції }\end{array}$} & \multirow[b]{2}{*}{ Походження } & \multirow{2}{*}{$\begin{array}{c}\text { Кіль-кість } \\
\text { гібридів, } \\
\text { шт. }\end{array}$} & \multicolumn{3}{|c|}{ Середня маса бульб, г } & \multirow[b]{2}{*}{$V, \%$} & \multicolumn{2}{|c|}{$\begin{array}{l}\text { Гібридів (\%) з середньою } \\
\text { масою бульб більшою, ніж }\end{array}$} \\
\hline & & & ліміти & $\begin{array}{l}\text { різниця } \\
\text { лімітів }\end{array}$ & $\bar{X} \pm \mathrm{S} \bar{X}$ & & $\begin{array}{c}\text { у кращої } \\
\text { батьківської } \\
\text { форми }\end{array}$ & $100 r$ \\
\hline 1 & Тетерів x Околиця & 4 & $17-40$ & 23 & $36 \pm 5,0$ & 10 & 0 & 0 \\
\hline 4 & Верді x Базис & 5 & $7-63$ & 56 & $40 \pm 5,0$ & 11 & 80 & 0 \\
\hline 5 & Верді x 81.459cl8 & 20 & $16-183$ & 167 & $45 \pm 4,5$ & 35 & 65 & 5 \\
\hline 6 & $\begin{array}{c}\text { Зелений гай x } \\
\text { Подолянка }\end{array}$ & 25 & 20-95 & 75 & $48 \pm 5,1$ & 18 & 76 & 0 \\
\hline 7 & Верді x Подолянка & 21 & $10-67$ & 57 & $41 \pm 4,8$ & 16 & 57 & 0 \\
\hline 8 & Тетерів x Подолянка & 35 & $10-90$ & 80 & $43 \pm 5,9$ & 17 & 9 & 0 \\
\hline 9 & 08.195/73 x Подолянка & 22 & 20-100 & 80 & $47 \pm 4,8$ & 21 & 73 & 5 \\
\hline 10 & 08.195/73x Партнер & 23 & $10-100$ & 90 & $45 \pm 6,9$ & 18 & 4 & 4 \\
\hline 11 & 08.195/73 x Лєтана & 38 & $20-80$ & 60 & $44 \pm 5,9$ & 20 & 11 & 0 \\
\hline 12 & 08.195/73 x Мілавіца & 14 & $17-80$ & 63 & $41 \pm 3,9$ & 20 & 64 & 0 \\
\hline 13 & 08.195/73 x Тирас & 38 & $10-250$ & 240 & $47 \pm 6,2$ & 39 & 21 & 3 \\
\hline 14 & 10.6Г38 x Подолія & 40 & $10-75$ & 65 & $36 \pm 6,4$ & 22 & 25 & 0 \\
\hline 15 & 10.6Г38 x Білоруська 3 & 33 & $20-85$ & 65 & $38 \pm 5,8$ & 16 & 27 & 0 \\
\hline 16 & Подолія x Базис & 8 & $10-50$ & 40 & $34 \pm 2,8$ & 14 & 25 & 0 \\
\hline 18 & Подолія x Струмок & 22 & $10-50$ & 40 & $30 \pm 4,8$ & 12 & 18 & 0 \\
\hline 19 & Пол. джерело х Базис & 14 & $10-45$ & 35 & $23 \pm 3,7$ & 10 & 7 & 0 \\
\hline 20 & Тетерів x Базис & 5 & $20-50$ & 30 & $41 \pm 2,2$ & 12 & 0 & 0 \\
\hline 21 & Тетерів x Струмок & 19 & $12-80$ & 68 & $37 \pm 4,4$ & 19 & 11 & 0 \\
\hline 22 & Базис x Тирас & 46 & $10-52$ & 42 & $32 \pm 6,7$ & 13 & 0 & 0 \\
\hline 23 & Базис x Подолія & 61 & $10-60$ & 50 & $29 \pm 5,8$ & 15 & 26 & 0 \\
\hline 24 & Струмок x Подолія & 12 & $15-130$ & 115 & $41 \pm 3,6$ & 17 & 67 & 8 \\
\hline 25 & Струмок х Явір & 11 & $10-50$ & 40 & $33 \pm 3,3$ & 13 & 27 & 0 \\
\hline 26 & Подолія x 81.459cl8 & 12 & $13-41$ & 28 & $26 \pm 3,3$ & 8 & 17 & 0 \\
\hline 28 & Багряна x 89.202c79 & 13 & $10-53$ & 43 & $24 \pm 3,7$ & 15 & 23 & 0 \\
\hline
\end{tabular}


комбінацій, у яких вираження показника було в межах 23-29 г. Різниця між крайнім значення прояву ознаки становила 2,1 рази, що, вважаємо значним. Поміж трьох популяцій за участю материнської форми сорту Верді не виявлено великої різниці середньої маси бульб у потомства. Вона знаходилась у межах 40-45 г.

Особливу реакцію на запилювача виявлено в блоці комбінацій за участю материнською формою беккроса 08.195/73. Серед потомства із запилювачами сортами Подолянка і Тирас величина показника, як уже згадувалось, була значною. Протилежне стосувалось потомства з сортом Мілавіца з середнім значенням показника 41 г, тобто на 6 г менше, ніж у комбінацій з сортами Подолянка і Тирас, що становило 15 \% від меншої величини.

Аналогічне викладеному вище відносилось бо комбінацій з материнською формою беккросом 10.6Г38. Відмінність між середнім значенням потомства у них була лише 2 г, хоча і з середньою величиною показника.

Дещо більша відмінність прояву ознаки виявлена в блоці комбінацій з сортом Тетерів. Найгіршою у цьому відношенні була популяція із запилювачем сортом Околиця 36 г, проте у двох інших з використанням сортів Подолянка і Базис середня маса потомства, відповідно, становила 43 і 41 г, тобто з дуже близькими значеннями показника.

Як свідчать отримані дані, невдалим для прояву ознаки серед потомства виявилось використання материнською формою сорту Подолія. По-перше в усіх трьох комбінаціях рівень середньої маси бульб був досить низьким - у межах 26-34 г. Крім цього, у популяції із запилювачем міжвидовим гібридом 81.459c18 отримані дуже низькі дані - 26 г, що обумовило різницю із потомством від схрещування Подолія х Базис 8 г.

Виявлений реципрокний ефект у двох пар схрещувань. Середня маса бульб потомства від гібридизації Подолія х Базис і Базис х Подолія різнилась на 5 г. Ще в однієї пари: Подолія х Струмок і Струмок х Подолія це становило 11 г з більшим впливом на прояв ознаки запилювача сорту Подолія.

У більшості комбінаціях від внутрішньовидових схрещувань отримані низькі значення середньої маси бульб. Мінімальне значення показника відмічено серед потомства від схрещування Подолія х Струмок-30 г. Близький прояв ознаки отриманий у популяції Струмок х Явір, хоча з походженням Струмок $x$ Подолія він виявився відносно високим - 41 г.
Вважаємо, через порівняно невелику різницю лімітів значення коефіцієнта варіації прояву середньої маси бульб поміж потомства відносно мале. У комбінації Подолія $\mathrm{x} 81.459 \mathrm{c} 18$ його величина становила лише 8 \%. Протилежне стосувалось популяцій Верді х 81.459c18 і 08.159/73 x Тирас, у яких він, відповідно, рівнявся 35 і 39 \%.

Практична цінність комбінацій визначається часткою потомства з вищим вираженням показника, ніж у кращої батьківської форми. Як свідчать отримані дані, популяції в цьому відношенні значно відрізнялись. У трьох з походженням Тетерів х Околиця, Тетерів х Базис і Базис $\mathrm{x}$ Тирас не виділеного жодного гібрида із згаданим проявом ознаки, що пояснюємо високим проявом показника хоча б у одного з батьків. Водночас, у 7 комбінаціях частка такого потомства становила більше 50 \% з максимальним вираженням її в гібридів з походженням Верді х Базис - 80 \% та Зелений гай х Подолянка - $76 \%$.

Порівняно невисокий загальний прояв ознаки серед потомства обумовив вищеплення лише поодиноких гібридів з середньою масою бульб 100 гі більше. Викладене стосувалось комбінацій Верді х 81.459c18, 08.195/73 x Подолянка, 08.195/73 х Тирас, 08.195/73 х Партнер і Струмок х Подолія. Крім цього, у кожній з них згадану характеристику мав лише один гібрид.

На рисунках 1а та 16 наведено графічне розміщення потомства популяцій 08.195/73 x Тирас і 10.6Г38 x Подолія за проявом у гібридів середньої маси бульб. Перший характеризувався тривершинністю, що, на нашу думку, обумовлено відмінностями генетичного контролю ознаки в батьківських форм. Іншому властива одновершинність 3 домінуванням класу, що мав найнижче вираження ознаки. У інших комбінаціях розподіл також специфічний.

Визначали кореляції основних показників, які характеризували середню масу бульб (табл. 3). Виконані підрахунки підтвердили щільну і пряму залежність між проявом ознаки в запилювачів та середнього батьків ( $r=0,76)$, а також середньо популяційного значення показника та середнього батьків $(r=0,71)$. У третини випадків (п'яти з 15-и) мала місце середня пряма залежність між показниками. Зокрема, вона часто повторювалась між часткою потомства з масою бульб 100 г і більше та часткою потомства з вищим проявом ознаки, ніж у кращої батьківської форми, середнього популяційного значення показника, проявом ознаки в материнських форм.

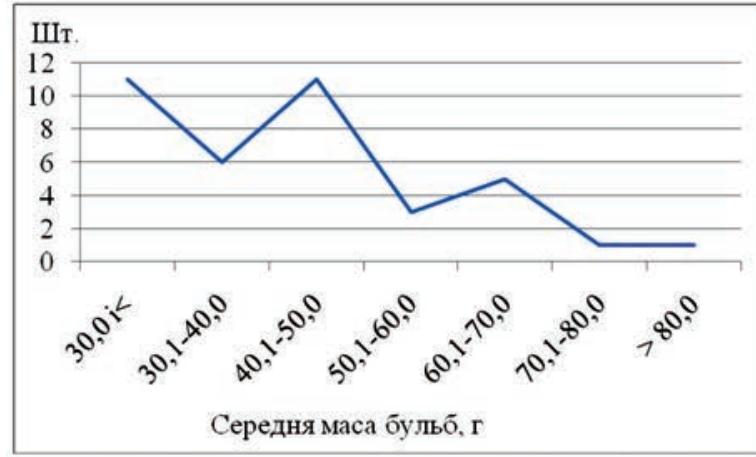

a

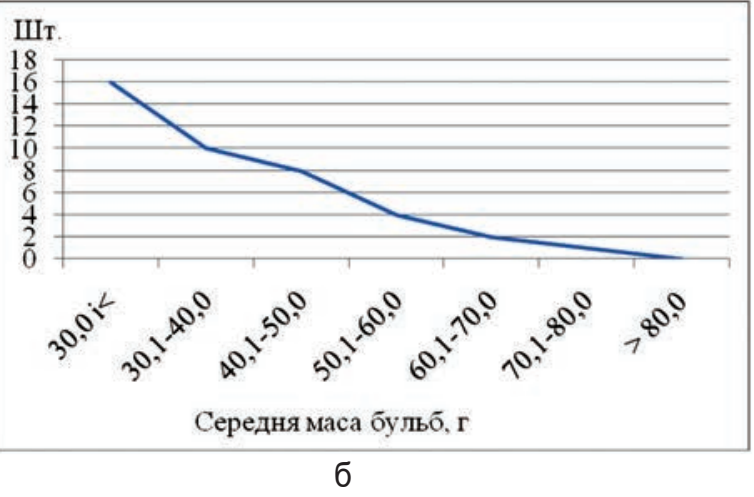

Рис. 1. Розподіл потомства комбінації 08.195/73 x Тирас (а) та 10.6Г38 х Подолія (б) за середньою масою бульб 
Тільки в двох випадках виявлена обернена середня залежність. Це стосувалось зв'язку між проявом ознаки в материнських форм та часткою потомства з вищим вираженням показника, ніж у кращої батьківської форми та останнього і середнього батьків.

Визначили ступінь фенотипового домінування в комбінаціях першого бульбового покоління за середньою масою бульб (рис. 3). У цілому, найчастіше зустрічалось проміжне успадкування показника, що мало місце в дев'яти популяціях, або 37,3 \% від їхньої загальної кількості. Ненабагато менше комбінацій (вісім, або 33,4 \% від усіх) характеризувалось депресією у прояві ознаки. У значної частини потомства (п'яти популяцій) відмічено наддомінування. Лише в окремих популяціях мало місце часткове позитивне домінування і часткове від'ємне успадкування.

В усіх комбінаціях за участю материнською формою сорту Верді мало місце наддомінування. Це ж стосувалось половини популяцій, де запилювачем використаний сорт Подолянка. В обох комбінаціях за реципрокного схрещування в одному випадку спостерігалось проміжне успадкування, а в іншому - депресія.

Вираховували величину істинного гетерозису (табл. 4). У блоці популяцій за участю материнської форми сорту Верді виявлене додатне значення показника, хоча воно знаходилось у значних межах - 5,3-66,7. у блоці із запилювачем сортом Подолянка додатне значення істинного гетерозису виявлене у трьох комбінаціях з чотирьох. Водночас, серед п'яти популяцій, де материнською формою був беккрос 08.195/73 лише в однієї величина істинного гетерозису була додатна. В усіх комбінаціях внутрішньовидового походження значення істинного гетерозису виявилось від'ємним.

За дуже рідкісним винятком (чотири популяції) краще за значенням показника потомство перевищувало кращу з батьківських форм. Максимально це спостерігалось у комбінаціях Верді х 81.459c18, Зелений гай х Подолянка, 08.195/73 х Подолянка, 08.195/73 х Мілавіца та 08.195/73 х Тирас. За винятком комбінації Струмок х Подолія за схеми внутрішньовидових схрещувань мало місце невисоке значення істинного гетерозису.

Виділено три популяції, у яких відсутні гібриди з вищим проявом ознаки, ніж у кращої батьківської форми, що обумовило нульове значення частоти трансгресії. Вод- ночас, у таких з них, як: Верді х Базис, Верді х 81.459c18, Зелений гай х Подолянка, 08.195/73 х Подолянка, 08.195/73 x Мілавіца та Струмок х Подолія величина показника була понад $65 \%$.

Обговорення. Оскільки складні міжвидові гібриди за участю фрілогенетично віддалених видів $€$ цінним вихідним селекційним матеріалом, їх досліджували в декількох експериментах. Співставлення одержаних результатів (Podhaietskyi et al., 2018) свідчать про значний вплив на величину середньої маси бульб потомства першого бульбового покоління зовнішніх умов періодів вегетації. У згаданій роботі максимальне середньопопуляційне значення показника становило 234 г (потомство від схрещування Багряна х 90.729/14), тоді як у висвітленій у статті воно було 48 г у комбінації Зелений гай х Подолянка.

Водночас, порівняння викладених даних вказує на значний вплив щодо прояву показника походження матеріалу. Середня популяційна маса бульб у дослідженнях згаданих авторів була в межах 21-234 г, а у викладених у статті - 23-48 г. Тобто за мінімальною величиною показника, отримані дуже близькі дані. У першому випадку це відмічене у комбінації Верді х 10.6/34, а в останньому Поліське джерело х Базис.

Підтверджений отриманий у наших дослідженнях реципрокний ефект від залучення у схрещування міжви-

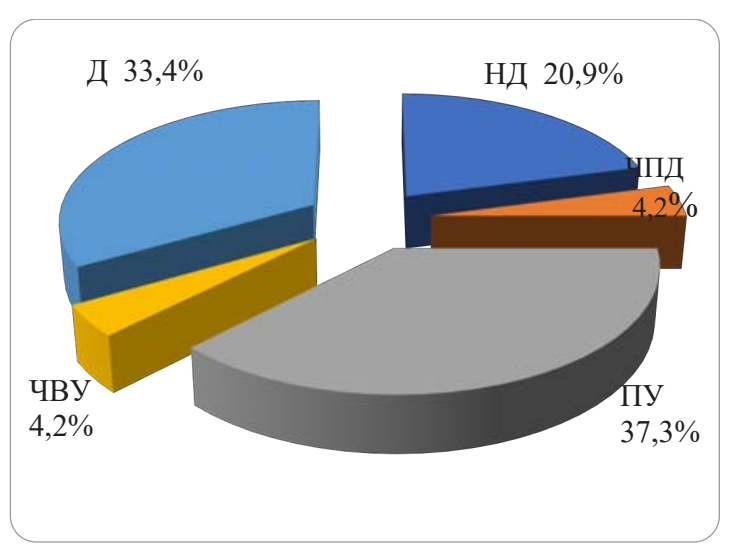
Рис. 3. Прояв ступеню фенотипового домінування за середньою масою бульб у комбінацій першого бульбового покоління

Таблиця 3

Кореляційна залежність (r) між середньою масою бульб батьківських форм, потомства і вищепленням цінних гібридів за ознакою, 2018 р.

\begin{tabular}{|c|c|c|c|c|c|c|}
\hline № 3/ח & Показник & $2^{*}$ & 3 & 4 & 5 & 6 \\
\hline 1 & Прояв ознаки у материнських фрорм & $-0,04$ & 0,63 & $-0,05$ & $-0,55$ & 0,40 \\
\hline 2 & Прояв ознаки у запилювача & & 0,76 & 0,14 & $-0,32$ & 0,06 \\
\hline 3 & Середнє батьків & & & 0,71 & $-0,60$ & $-0,03$ \\
\hline 4 & Середнє популяційне & & & & 0,43 & 0,45 \\
\hline 5 & $\begin{array}{c}\text { Частка потомства з вищим проявом ознаки, ніж у кращої } \\
\text { батьківської фооми }\end{array}$ & & & & & 0,40 \\
\hline 6 & Частка потомства з масою бульб 100 г і більше & & & & & \\
\hline
\end{tabular}

Примітка: цифри відповідають № 3/п першого стовпчика i, тим самим, показникам 
Прояв істинного гетерозису $\left(\Gamma_{\text {ic }}\right)$, ступеня трансгресії $\left(T_{c}\right)$ i частоти трансгресії $\left(T_{4}\right)$ за середньою масою бульб потомства комбінацій першого бульбового покоління (\%), 2018 р.

\begin{tabular}{|c|c|c|c|c|}
\hline № популяції & Походження & $\Gamma_{\text {ict }}$ & $T_{c}$ & $T_{4}$ \\
\hline 1 & Тетерів х Околиця & $-42,9$ & $-41,3$ & 0,0 \\
\hline 4 & Верді х Базис (85.291с12 - В² шестивидового гібрида х Багряна) & 5,3 & 55,3 & 80,0 \\
\hline 5 & Верді x 81.459c18 - шестивидовий гібрид & 66,7 & 251,9 & 65,0 \\
\hline 6 & Зелений гай x Подолянка - $\mathrm{F}_{2} \mathrm{~B}^{1}$ шестивидового гібрида & 37,1 & 134,3 & 76,0 \\
\hline 7 & Верді x Подолянка & 17,1 & 80,0 & 57,1 \\
\hline 8 & Тетерів х Подолянка & $-31,7$ & 23,8 & 8,6 \\
\hline 9 & 08.195/73 - В² шестивидового гібрида х Подолянка & 34,3 & 151,4 & 72,7 \\
\hline 10 & 08.195/73 x Партнер & $-46,4$ & 1,2 & 4,3 \\
\hline 11 & 08.195/73 x Лєтана & $-18,5$ & 61,1 & 10,5 \\
\hline 12 & 08.195/73 x Мілавіца & 17,1 & 105,7 & 64,3 \\
\hline 13 & 08.195/73 x Тирас & $-14,5$ & 140,0 & 21,1 \\
\hline 14 & 10.6ГЗ8 - В5 шестивидового гібрида х Подолія & $-21,7$ & 52,2 & 25,0 \\
\hline 15 & $10.6 Г 38$ x Білоруська 3 & $-17,4$ & 34,8 & 27,3 \\
\hline 16 & Подолія x Базис & $-10,5$ & 21,1 & 25,0 \\
\hline 18 & Подолія x Струмок & $-34,8$ & 8,7 & 18,2 \\
\hline 19 & Поліське джерело х Базис & $-44,7$ & $-7,9$ & 7,1 \\
\hline 20 & Тетерів x Базис & 7,9 & 31,6 & 0,0 \\
\hline 21 & Тетерів x Струмок & $-41,3$ & 11,1 & 10,5 \\
\hline 22 & Базис x Тирас & $-41,8$ & $-5,5$ & 0,0 \\
\hline 23 & Базис x Подолія & $-23,7$ & 92,1 & 26,2 \\
\hline 24 & Струмок x Подолія & $-10,9$ & 71,7 & 66,7 \\
\hline 25 & Струмок x Явір & $-57,7$ & $-35,9$ & 27,3 \\
\hline 26 & Подолія x 81.459c18 & $-16,1$ & 16,1 & 16,7 \\
\hline 28 & Багряна x 89.202c79 - В¹ шестивидового гібрида & $-42,9$ & 16,7 & 23,1 \\
\hline
\end{tabular}

дових гібридів. Використання сорту Ірбицька запилювачем обумовила частку потомства у дев'яти популяціях в класі 30 г і менше $25 \%$, а у зворотних схрещуваннях таких гібридів не було (Kravchenko et al., 2019). Навпаки, більш перспективним виявилось використання сорту Багряна запилювачем.

Висновки. Виявлено вище варіювання середньої маси бульб у сортів (18-84 г), порівняно з міжвидовими гібридами, їх беккросам (27-46 г). Навпаки, найбільше значення нижньої межі лімітів популяцій від внутрішньовидового схрещування було 15 г, а від беккросування у п'яти комбінацій (25 \% від усіх) - 20 г. Подібне стосувалось верхньої межі лімітів, відповідно, 130 і 205 г. Доведено, що різниця між середнім популяційним проявом показника значно більша серед комбінацій від беккросування (25 г з межами 23-28 г), ніж від внутрішньовидових схрещувань, відповідно, 11 і 30-41 г. Виявлений значний вплив компонентів схрещування на прояв ознаки серед потомства.
Встановлено найбільший вплив запилювачів на прояв середньої маси бульб поміж потомства за участю сорту Подолія. Різниця між комбінаціями становила 8 г. Лише невеликою мірою поступались їй блоки популяцій з сортами Тирас (материнська форма) і Подолянка (запилювач - 7 г), Протилежне стосувалось двох комбінацій 3 материнською формою беккросом 10.6Г38 - 2 г. Встановлений реципрокний ефект середнього прояву ознаки в потомства за участю сортів Базис і Подолія (різниця 5 г) та Струмок і Подолія з різницею 11 г. Тільки в однієї комбінації від внутрішньовидових схрещувань та в чотирьох від беккросування виділені гібриди з середньою масою бульб 100 г і більше. Лише в семи популяціях (29 \% від загальної кількості) величина істинного гетерозису мала додатне значення, хоча це не відносилось до жодної з внутрішньовидовим походженням. У 20-и комбінаціях ступінь трансгресії мав додатну величину і лише в трьох не виявлено частоти трансгресії.

\section{Бібліографічні посилання:}

1. Antonova, O. Yu., Shvachko, N. A., Novykova, L. Yu., Shuvalov, O. Yu., Kostyna, L. Y., Klymenko, N. S., Shuvalova, A. R., \& Havrylenko, T. A. (2016). Henetycheskoe raznoobrazye sortov kartofelia rossyiskoi selektsyy y stan blyzhneho zarubezhia po dannыm polymorfyzma SSR-lokusov y markerov R-henov ustoichyvosty [Genetic diversity of potato varieties of Russian breeding and neighboring countries according to the data of polymorphism of SSR-loci and markers of R-resistance genes]. Vavylovskyi zhurnal henetyky y selektsyy, 20(5), 596-606 (in Russian). doi: 10.18699/VJ16.181.

2. Banadysev, S. A., Starovojtov, A. M., Koljadko, I. I., Mahan'ko, V. L., Fando, V. V., \& Kozlova, L. I. (2003). Metodicheskie rekomendacii po specializirovannoj ocenke sortov kartofelja [Methodical recommendations for specialized assessment of potato varieties]. Ministerstvo sel'skogo hozjajstva i prodovol'stvija Respubliki Belarus'. Minsk, 70 (in Russian).

3. Bondus, R. O., Podhaietskyi, A. A., \& Tokman, V. S. (2009). Otsinka serednorannikh sortiv kartopli - skladovykh kolektsii Ustymivskoi doslidnoi stantsii [Evaluation of middle-early varieties of potatoes - components of the collection of Ustymivka station]. Henetychni resursy roslyn, 7, 164-173 (in Ukrainian). 
4. Bradshaw, J. (2009). Potato breeding at the Scottish Plant Breeding Station and the Scottish Crop Research Institute: 1920-2008. Potato Res., 52, 141-172. doi: 10.1007/s11540-009-9126-5.

5. Castaneda-Alvares, N. P., de Haan, S., Juarez, H., Khoury, C. K., Achicanoy, H. A., Sosa, C. C., Bernau, V. V., Salas, A., Heider, B., Sinon, R., Maxted, N., \& Spooner, D. (2015). Ex situ conservation priorities for the wild relatives of potato (Solanum L. section Petota). PLoS ONE, 10(4), doi: 10/1371/journal.pone.0122599.

6. Gopal, J., Gaur, P. C., \& Rana, M. S. (1992). Early generation selection for agronomic characters in a potato breeding programme. Theor. Apll. Gen., 84, 709-713.

7. Kiru, S. D., \& Rogozina, E. V. (2017). Mobilization, conservation and study of cuktivated and wild potato genetic resources. Vavilov journal of genetics and breeding. 2017. 21(1), 7-15. doi: 10.18699/VJ17.219.

8. Kovalenko, V. M. (2013). Adaptyvnyi potentsial sortiv kartopli riznykh selektsiinykh ustanov [Adaptive potential of potato verieties of different breeding institutions]. Dys. k.s.-h.n: 06.01.05. Sumskyi NAU, Sumy, 193 (in Ukrainian).

9. Kravchenko, N. V., Podhaietskyi, A. A, \& Sobran, I. V. (2019). The average weight of tubers of the second vegetative generation of offspring from backcrossing of complex interspecific hybrids of potatoes. Proceedings of the VIII International Scientific Conference "Breeding and Genetic Science and Education". March 18-20, 2019. Uman, 114-115 (in Ukrainian).

10. Meenakshi, Kumari; Manoj, Kumar; Shcshcank, Shekhar Solankey. (2018). Breeding Potato for Quality Improvement. Submited: May 8th 2017 Reviewed: October 5-th 2017 Published; June 6th 2018. doi: 10.5772/intechopen.71482.

11. Mendoza, H. A., \& Haynes, F. L. (1973). Some aspects of breeding and inbreeding in potatoes. Am. Pot. J., 50. $216-222$.

12. Metodychni rekomendatsii shchodo provedennia doslidzhen z kartopleju [Methodical recommendations for research with potatoes] (2003). Nemishaieve, 83 (in Ukrainian).

13. Moller, K. H. (1965). Untersuchungen an Testkreuzungen zur Auswahl geeigneter Eltern und Kombinationen in der Kartoffelziichtung. Diss. Dt. Akad. Land-wirtschaftswiss., Berlin (in German).

14. Osypchuk, A. A. (2002). Henetychnyi potentsial kartopli [Genetic potential of potatoes]. Kartoplia. T1, Kyiv, 203-204 (in Ukrainian).

15. Podhaietskyi, A. A. (2012). Mezhvidovaja gibridizacija v selekcii kartofelja v Ukraine [Interspecies crosses in potato breeding in Ukraine]. Vavilov journal of genetics and breeding. 2, 16, 471-479 (in Russian).

16. Podhaietskyi, A. A., Kovalenko, V. M., \& Kyienko, Z. B. (2014). Ocinka sortiv selekcii' Instytutu kartopljarstva NAAN za seredn'oju masoju bul'b u riznyh umovah [Evaluation of varieties of selection of the Institute of Potato NAAS on the average weight of tubers in different conditiond]. Kartopliarstvo Ukrainy, 3-4(36-37), 25-31 (in Ukrainian).

17. Podhaietskyi, A. A., Kravchenko, N. V., \& Sobran, I. V. (2018). The average weight of offspring tubers from backcrossing of complex interspecific potato hybrids in the first tuber generation. Proceedings of the scientific conference "Current status and prospects for the development of selection and seed production of potatoes." July 10, 2018, Moscow. NIIKH, 71-79 (in Russian).

18. Rokytskyi, P. F. (1973). Byolohycheskaya statystyka. Vysheishaia shkola, Mynsk, 319.

19. Ross, H. (1986). Potato breeding - problems and perspectives. Paul Parey, Berlin and Hamburg, 132.

20. Rowe, P. R. (1967). Performance and variabiality of diploid and tetraploid potato families. Am. Pot. J., 44, $263-271$.

21. Sainakova, A. B., Romanova, M. S., Krasnykov, S. N., Lytvynchuk, O. V., Alekseev, A. Y., Nykulyn, A. V., Terenteva, E. V. (2018). Issledovanie kollekcionnyh obrazcov kartofelja na nalichie geneticheskih markerov ustojchivosti $k$ fitopatogenam [Study of collection potato samples for the presensce of genetic markers of resistance to phytopathogens]. Vavylovskyi zhurnal henetyky y selektsyy, 22(1), 18-24 (in Russian). doi: 10.18699/VJ18.326.

22. Schick, R., \& Hopfe, A. (1962). Die Zuchtung der Kartoffel. Die Kartoffel. Bd. II. Berlsn: Veb. Dtsch.Landwirtsch, 1462 (in German).

23. Slater, A., Cogan, N., Benjamin, J., Hayes, B., Kee, S., Finlay, M., Dale, B., Gleen, J., Bryan, J., \& Foster, W. (2014). Improving dreeding tfficiency in potato using molecular and Quantitative genetics. Theor. Appl. Genet., 127(11), $2279-2292$. doi: 10.1007/s00122-014-2386-8.

24. Skiebe, K. (1977). Die genetischen Ursachen von Hybrideffekten. Biol. Zentialbl. 96, 303-319 (in German).

Podgaetsky A. A., Doctor (Agricultural Sciences), Professor, Sumy National Agrarian University, Sumy, Ukraine

Kravchenko N. V., Doctor (Agricultural Sciences), Associate Professor, Sumy National Agrarian University, Sumy, Ukraine

Kryuchko L. V., PhD (Agricultural Sciences), Associate Professor, Sumy National Agrarian University, Sumy, Ukraine

Gnitetsky M. O., PhD student, Sumy National Agrarian University, Sumy, Ukraine

Manifestation among the off springs of the first tuber generation of hybrids from intraspecies and interspecies crossings of the middle mass of tubers

The results of the study indicate a higher variation of the average weight of tubers in varieties-components of crossing (18-84 g), compared with interspecific hybrids, their backcrosses (27-46 g). In contrast, the maximum value of the lower limit of population limits from intraspecific crossing was $15 \mathrm{~g}$, and from backcrossing in five combinations (25\% of all) - $20 \mathrm{~g}$. The same applied to the upper limit of limits, respectively, 130 and $205 \mathrm{~g}$.

It is proved that the difference between the average population manifestation of the indicator is much larger among the combinations from backcrossing (25 g with a range of 23-48 g) than from intraspecific crosses, respectively, 11 and 30-41 g.

The greatest influence of pollinators on the manifestation of the average mass of tubers among the offspring with the participation of the Podolia variety was established. The difference between the combinations was $8 \mathrm{~g}$. Population blocks with varieties Tiras (maternal form) and Podolyanka (pollinator $-7 \mathrm{~g}$ ) were only slightly inferior to it. traits in the offspring with the participation of varieties Basis and Podolia (difference $5 \mathrm{~g}$ ) and Stream and Podolia with a difference of $11 \mathrm{~g}$

Only in one combination from intraspecific crosses and in four from backcrossing hybrids with an average weight of tubers of $100 \mathrm{~g}$ and more were isolated. Only in seven populations (29\% of the total) was true heterosis positive, although this did not apply to any of the intraspecific origin. In 20 combinations, the degree of transgression was positive and only three did not show the frequency of transgression.

Key words: potatoes, intraspecific and interspecific crosses, average weight of tubers, parental forms, reciprocal effect, heterosis, transgressions, degree of phenotypic dominance. 